\title{
Vulnerability of forest resources to global climate change: case study of Cameroon and Ghana
}

\author{
Robert K. Dixon ${ }^{1}$, James A. Perry ${ }^{2}$, Elizabeth L. Vanderklein ${ }^{2}$, Francois Hiol Hiol ${ }^{3}$ \\ ${ }^{1}$ U.S. Country Studies Program, Washington, DC 20585, USA \\ ${ }^{2}$ Department of Forest Resources, University of Minnesota, St. Paul, Minnesota 55108, USA \\ ${ }^{3}$ Department of Forestry, University of Dschang, Dschang, Cameroon
}

\begin{abstract}
The response and feedbacks of forest systems to global environmental change, including the ecosystems of West Africa, are expected to be profound. A comparative assessment of current and future forest distribution in Cameroon and Ghana in response to land-use change and global climate change was completed. From 1970 to 1990, the forest area of Cameroon and Ghana declined dramatically due to harvesting and degradation, averaging 0.6 and $1.3 \%$ each year, respectively. The areal distribution of West African forest systems is projected to shift 5 to $15 \%$, based on 4 General Circulation Model (GCM) scenarios and the Holdridge Life Zone Classification System. Loss of forest habitat due to destruction, degradation and climate change is projected to increase animal and plant species loss. Adaptation of evergreen and deciduous forest systems to global environmental change poses many challenges for Cameroon and Ghana. Application of low-input, indigenous resource management options, which have been practiced on a sustained basis for centuries, may be a feasible adaptation goal.
\end{abstract}

KEY WORDS: Cameroon · Carbon pools and flux · Forest systems · Ghana - Mitigation

\section{INTRODUCTION}

The accumulation of greenhouse gases in the atmosphere due to land-use change, fossil fuel combustion and other human activities may have begun to change the global climate (Schneider 1989, IPCC 1995). The response and feedbacks of the terrestrial biosphere to projected global climate change are expected to be profound (Smith et al. 1991, 1993). Large shifts in the distribution and productivity of vegetation, especially forest systems, are implied by the climate change scenarios of General Circulation Models (GCMs) (Neilson et al. 1994). Globally, the area of tropical and temperate forests is projected to expand by up to $20 \%$, whereas boreal forests could decrease up to $50 \%$ (Krankina \& Dixon 1993). Grasslands, savannas, and shrublands may significantly increase in areal extent, particularly in zones of marginal productivity due to limiting edaphic factors (Prentice et al, 1992). Even if the GCM scenarios are only partially correct, the productivity of existing forest and agroecosystems in zones of marginal productivity, such as sub-Saharan Africa, will inevitably change (Gleick 1989).

The countries of sub-Saharan West Africa, including Guinea, Côte d'Ivoire, Togo, Ghana, Nigeria, and Cameroon, all span a wide range of climatic and edaphic zones. Several coarse ecoregions have been identified in the sub-Saharan zones from south to north: coastal mangroves, lowland rain forest, coastal grass and shrublands, Guinea sudan (woodlands), semi-desert grass and shrublands, and desert (Hall \& Swaine 1981). Precipitation, strongly influenced by the Atlantic Ocean, is relatively abundant and distributed seasonally in the coastal zone of West Africa, but amounts decrease dramatically inland. During this century, West Africa has experienced marked fluctuations in rainfall amount and distribution, influencing vegetation distribution and productivity (Glantz \& Katz 1985, Hellden 1992). Climate variability, in combination with fragile soil systems, many of which have low organic matter, low fertility and CEC, and high bulk density (Barrett-Lennard et al. 1986), have influenced 
land-use patterns, sustainable development of natural resources, and environmental integrity of this region (Bushbacher 1992)

The nations of West Africa, especially Cameroon and Ghana, were once well endowed with forest resources (Barnes 1990, Brown et al. 1993). Forests offer many timber and non-timber goods and services for the rapidly growing agrarian economies of these 2 countries, despite contrasting colonial histories and natural resource management patterns (Gregerson et al. 1989, Bushbacher 1992). Degradation and loss of forests in both Cameroon and Ghana have increased sharply in recent decades (Dixon et al. 1996). Tracts of relatively undisturbed forest harbor abundant biodiversity (Alpert 1993), protect fragile soils (Gartlan 1986), and modulate the supply of scarce water resources (Glantz \& Katz 1985, Gilbert et al. 1995).

The objective of this assessment is to: (1) characterize current and future areal distribution of forest resources in Cameroon and Ghana, based on changes in land-use and global climate, and (2) identify potential options for forest system adaptation.

\section{METHODS}

Statistical information on forest type and areal extent (Singh 1993), biomass and carbon density (Dixon et al. 1994), species richness and loss (Alpert 1993), forest area change (Unruh et al. 1993), and greenhouse gas emissions (Graham et al. 1990) was compiled from information based on national forest surveys in Africa. This information was supplemented by Advanced Very High Resolution Radiometer (AVHRR) analysis of land-use patterns (Unruh et al. 1993, Trexler \& Haugen 1995). A database of statistical information was compiled and, where appropriate, a Geographic Information Systern (GIS) was employed to validate and calibrate disparate information (Iverson et al. 1993, Dixon et al. 1994).

The potential effects of global climate change on vegetation in West Africa were estimated using scenarios of future climate produced by GCMs and the Holdridge Life Zone Classification (Holdridge 1967. Smith et al. 1991). The Holdridge Classification relates the major plant formations in the world to 2 independent climate variables, biotemperature (growing season index) and total annual precipitation. Climate change scenarios (doubled atmospheric $\mathrm{CO}_{2}$ ) produced by the Geophysical Fluid Dynamics Model (GFDL: Manabe \& Wetherald 1987), Goddard Institute for Space Studies (GISS Hansen et al. 1983), Oregon State University (OSU; Schlessinger \& Zhao 1989), and
United Kingdom Meteorological Office (UKMO; Mitchell et al. 1989) were used to drive the Holdridge Life Zone Classification. Although the Holdridge system has many life-zone classifications, most are not applicable to this analysis. Thus, climate change impacts are summarized for 3 ecoregions: evergreen forest, deciduous forest, and hill and montane systems. The future vegetation scenario is best interpreted as a sensitivity analysis given the limitations of both GCMs and Holdridge Model (Prentice et al. 1992).

The relationship between forest habitat change and species change or loss was estimated using the species-area model of McArthur \& Wilson (1967), using methods modified for low latitude forest systems by Lugo et al. (1993). The equation $S=C A^{Z}$, where $S=$ number of species, $A=$ forest area, and $C$ is a parameter that depends on the taxon, its population density and biogeographic region, was employed. The species-area relationship is determined by the $Z$ factor that ranges from 0.2 to 0.7 for West Africa plant and animal habitats (Lugo et al. 1993). $Z$ factors greater than 0.6 suggest that species change or loss is proportional to forest area change, greater than recent empirical data suggest possible (Alpert 1993). Thus, potential rates $(\%)$ or animal and plant change are presented Given that forest area may expand in West Africa due to climate change impacts, change estimates should not necessarily be viewed as species loss estimates. Species change due to climate-change induced losses of forest habitat have large variance terms and should be viewed as a sensitivity analysis given the limitations of existing models (Smith et al. 1991)

\section{RESULTS}

From 1970 to 1990 , the forest area of Ghana declined by $50 \%$ and the proportion of degraded or semi-arid land increased (Table 1). Annual deforestation in Ghana was approximately 122000 ha before large areas of primary forests were depleted. The indigenous forests of Ghana have been partially replaced with cocoa, oil palm, citrus, and rubber plantations in ecoregions with adequate site conditions (Gilbert et al. 1995). Although forest harvesting is widespread in

Table 1. Trends in closed forest area and deforestation in Cameroon and Ghana (Singh 1993)

\begin{tabular}{|c|c|c|c|c|}
\hline & \multicolumn{2}{|c|}{$\begin{array}{l}\text { Total closed forest } \\
\text { area }\left(\times 10^{6} \mathrm{ha}\right\}\end{array}$} & \multirow[t]{2}{*}{$\begin{array}{l}\text { Annual deforestation } \\
1980-1990\left(\times 10^{3} \text { ha }\right)\end{array}$} & \multirow{2}{*}{$\begin{array}{c}\text { Peak annual } \\
\text { deforestation } \\
(\%)\end{array}$} \\
\hline & 1970 & 1990 & & \\
\hline Cameroon & 24200 & 16500 & 137 & -0.6 \\
\hline Ghana & 3700 & 1718 & 122 & -1.3 \\
\hline
\end{tabular}




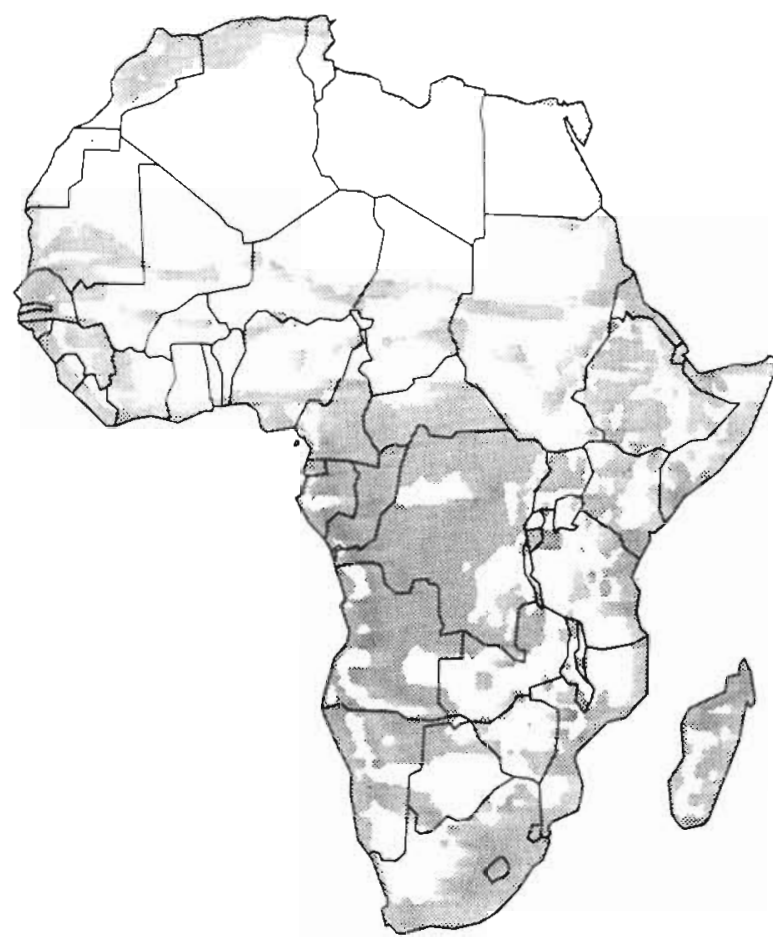

Fig. 1. Area of vegetation change in Africa based on UKMO GCM scenario and Holdridge (1967) life form classification system (after Smith et al. 1991)

Cameroon, the relative reduction in closed forest area is less than in Ghana. A smaller human population, inaccessibility of forests, and different resource management patterns have slowed the loss of forests in Cameroon in recent decades (Alpert 1993). Despite efforts to slow forest loss, the annual rate of deforestation in Cameroon and Ghana is 0.6 and $1.3 \%$, respectively.

With a doubling of atmospheric $\mathrm{CO}_{2}$ in the next century, significant shifts in the areal extent and distribution of forest vegetation are projected for the continent of Africa (Fig. 1). The Holdridge model driven by the UKMO GCM projects large vegetation changes in southwestern Africa and in most coastal zone ecoregions. On a continental scale, up to $40 \%$ of the vegetation in Africa may shift in response to this climate change scenario. Grasslands, savannas and shrublands may increase dramatically as precipitation and forest systems decline.

Shifts in the areal extent of forests in Cameroon and Ghana are projected by the 4 GCM scenarios (Table 2). The GISS, OSU, and UKMO scenarios, as simulated by the Holdridge Life Form Classification System, project the same direction of change in evergreen, deciduous and montane forests. Generally, these 3 scenarios predict an expansion in forest area, but the magnitude of change differs appreciably. The GFDL scenario projects a possible decrease in forest area, in contrast to the other 3 scenarios.

Deforestation, forest degradation, and future global climate change significantly influence the projected rate of animal and plant species change in Africa (Table 3). Current species loss due to forest degradation and destruction ranged from 1 to $2.5 \%$, depending on ecoregion. Cameroon has the highest number of species in West Africa and over 40 and 100 globally threatened animals and plant species, respectively. The lowland evergreen forests of Cameroon have the greatest proportion of biological diversity and suffer high rates of annual forest loss. In comparison, Ghana has far fewer animal and plant species, including approximately 400 tree and shrub species. A rapid rate of climate change is projected to alter species occurrence in Africa, including Cameroon and Ghana. The uncertainty regarding the error terms of future species loss estimates is unknown due to inability to model the variance around the magnitude rate of global climate change.

The rate of global climate change is of equal or greater importance than the direction or magnitude because it affects the ability of forest ecosystems and human institutions to adapt to a changing environment. A summary of low latitude forest adaptation options, with an emphasis on West Africa, is presented in Table 4. Active vegetation and soil management, such as silvicultural practices, endangered species habitat management, watershed manipulation, and anti-desertification techniques, could be applied given current infrastructure in Cameroon and Ghana (Gilbert et al. 1995). These reactionary and anticipatory

Table 2. Current forest ecoregion area and the effect of future climate change on annual extent of forests in Cameroon and Ghana under 4 GCM scenarios (after Smith et al. 1991)

\begin{tabular}{|lcrrrr|}
\hline Nation & Current & \multicolumn{5}{c|}{ GCM scenario $\left(2 \times \mathrm{CO}_{2}\right)$} \\
Ecoregion & & GISS & OSU UKMO & GFDL \\
& & \multicolumn{4}{c}{ UK } \\
& & & & & \\
\hline Cameroon & & & & \\
$\quad$ Evergreen forest & 8021 & 8663 & 8984 & 8181 & 7620 \\
Deciduous forest & 10477 & 11315 & 11734 & 10687 & 9953 \\
Hill and montane & 1767 & 1908 & 1979 & 1802 & 1679 \\
Ghana & & & & & \\
Evergreen forest & - & - & - & - & $\ldots$ \\
Deciduous forest & 9555 & 10319 & 10702 & 9746 & 9077 \\
Hill and montane & 480 & 518 & 538 & 490 & 456 \\
\hline
\end{tabular}


Table 3. Estimates of plant and animal species abundance and change in Africa (after Alpert 1993, Singh 1993)

\begin{tabular}{|lccc|}
\hline Ecoregion & $\begin{array}{c}\text { Current estimated } \\
\text { species abundance }\end{array}$ & $\begin{array}{c}1980-1990 \text { species loss } \\
\text { due to deforestation (\%) }\end{array}$ & $\begin{array}{c}\text { UKMO GCM scenario }\left(2 \times \mathrm{CO}_{2}\right) \\
\text { Simulated species change }(\%)\end{array}$ \\
\hline Evergreen forest & 30700 & 2.0 & 5.0 \\
Deciduous forest & 13000 & 2.5 & 3.0 \\
Hill and montane & 1900 & 1.0 & 3.0 \\
Semi-arid and savanna & 1.2300 & 2.5 & 2.5 \\
\hline
\end{tabular}

Table 4. Examples of global climate change impacts on low latitude forest resources and potential adaptive measures or responses in Cameroon and Ghana

\begin{tabular}{|lll|}
\hline Component/system & Potential impact & Adaptive responses \\
\hline Forest plant community & $\begin{array}{l}\text { Shift in composition, productivity and } \\
\text { reproduction; decline, dieback or migration of } \\
\text { species; insect and pathogen range shifts }\end{array}$ & $\begin{array}{l}\text { Silvicultural measures such as artificial } \\
\text { regeneration, thinning, or fertilization } \\
\text { pest management }\end{array}$ \\
Forest animal community & $\begin{array}{l}\text { Shift in composition; loss of habitat and diversity; } \\
\text { species migration or invasion problems; } \\
\text { pest problems }\end{array}$ & $\begin{array}{l}\text { Habitat or species preservation; estab- } \\
\text { lish migration corridors; enhance sup- } \\
\text { port for existing parks and bioreserves }\end{array}$ \\
Forest watershed resources & $\begin{array}{l}\text { Change in water quantity and quality; } \\
\text { extreme events; loss of aquatic habitat }\end{array}$ & $\begin{array}{l}\text { Water management options such as } \\
\text { reservoir development, flood protection, } \\
\text { habitat protection, fish hatcheries, } \\
\text { integrated watershed management } \\
\text { Semi-arid woodlands }\end{array}$ \\
& $\begin{array}{l}\text { Soil and vegetation protection; } \\
\text { fertilization or irrigation; minimize site } \\
\text { disturbance via sustainable systems }\end{array}$ \\
\hline
\end{tabular}

adaptive responses will help reduce climate change impacts on forest communities, forest watersheds, and semi-arid woodlands.

\section{DISCUSSION}

A century ago, closed forests extended across equatorial Africa from Senegal to Zaire (Barnes 1990). In West Africa from Senegal to Nigeria, these forests have been harvested and degraded, including those occurring in Ghana. In central Africa, closed forests are less disturbed. Cameroon lies between these 2 regions and retains approximately $40 \%$ of its indigenous forests more than any other coastal West African country (Hall \& Swaine 1981, Alpert 1993). Cameroon and Ghana have growing agrarian economies and their forests are threatened by harvesting, degradation, and desertification in the near-term and possibly global climate change in the next century.

The causes of forest loss and degradation in Cameroon and Ghana are associated with economic development pressures: rapid population growth and urbanization, and demand for food, fuel and fiber, concentration of land ownership, national natural resource policies, and cultural/historical factors (Foley 1987, Barnes 1990). Resource-poor farmers, timber concessionaires, ranchers, and traditional shifting cultivators all contribute to forest loss and decline (Boonkird et al. 1991). Compounding these development pressures are government investment policies, tax and credit practices, and logging concessions (Gregerson et al. 1989, Trexler \& Haugen 1995). Subsistence and small-scale commercial exploitation are more important than large-scale exploitation in Cameroon, but large-scale commercial logging is significant in Ghana. Government policy encourages natural resource development. especially commercial wood utilization (Sampson et al. 1993). Foreign enterprises hold up to $75 \%$ of the logging concessions. Desertification and large-scale water management schemes also threaten the areal extent of forests (Glantz \& Katz 1985, Hellden 1992).

Loss of forests in Cameroon and Ghana has contributed to the emission of greenhouse gases to the atmosphere and the degradation of land (soil system) productivity and fostered desertification (Sanchez \& Benites 1987). Harvesting, degradation, and combustion of forests contribute $\mathrm{CO}_{2}, \mathrm{CH}_{4}$ and $\mathrm{N}$ compounds to the atmosphere (Graham et al. 1990, Hogan \& Leng 1992), with estimated greenhouse gas emissions of 
0.25 to $0.45 \mathrm{Pg} \mathrm{C}$ annually from the continent of Africa (Dixon et al. 1994). Deforestation and intensive cropping of fragile soil systems have contributed to a rapid decline in soil biological, chemical, and physical properties. Loss of soil organic matter contributes to a decline in crop production and an increase in $\mathrm{C}$ and $\mathrm{N}$ emissions to the atmosphere (Lugo et al. 1986, Hall \& Rosilo-Calle 1990). Land previously considered marginal for production is now under cultivation in many ecoregions (Grainger 1988). Anthropogenic factors (e.g. deforestation) are linked to the desertification of formerly stable and productive lands (Hellden 1992).

Dramatic shifts in the areal extent, distribution, condition, and reproduction of low-latitude forests are predicted with a future change in global climate (Prentice et al. 1992, Smith et al. 1993). During this century the African continent has experienced marked fluctuations in precipitation amount and distribution, with commensurate impacts on vegetation and land-use patterns (Glantz \& Katz 1985, Hellden 1992). Recent changes in the regional climate of sub-Saharan Africa have been gradual, but future changes may be more rapid, with large, more dramatic impacts on vegetation, soils and human institutions (Gleick 1989).

The climate scenarios presented in this report should be viewed as a sensitivity analysis due to the limitations of GCMs and the Holdridge models (Holdridge 1967). For example, the Holdridge model is steadystate, not dynamic, and does not consider $\mathrm{CO}_{2}$ enrichment impacts on plant water-use efficiency or seasonality of precipitation (Prentice et al. 1992). Species migration and succession within ecoregions will probably be important survival strategies in a changing global climate but are not considered in the Holdridge model (Neilson et al. 1994). Finally, current models are formulated using correlations between present vegetation and climate, ecological relationships that may change in a future global environment (Neilson et al. 1991).

Threats to the abundance of biological diversity in Cameroon and Ghana include forest loss, desertification and future global climate change (Alpert 1993). Although species abundance in West Africa is relatively low compared to southeast Asia or Amazonia, the current loss of animal and plant species due to anthropogenic factors is significant (Singh 1993). The current system of legally protected areas (national parks, faunal reserves, bioreserves, protected forests) in Cameroon and Ghana is relatively elaborate in size and distribution, but progressive forest degradation and species loss is accelerating due to socioeconomic factors (Barnes 1990). In a changing global climate, forest species shifts could occur through a slow, deliberate process of competitive displacement (via migration and succession), with the effects of this displace- ment on ecoregion structure and function minimal (Smith \& Tirpak 1989). However, if forest habitat shifts rapidly in response to climate change, species change could be dramatic (Neilson et al. 1994). Species-impoverished forest systems may be at greatest risk (Alpert 1993); however, ecosystem resiliency has been greater than current models predict (Lugo et al. 1993)

Warfare, severe cyclic droughts, crop failures, and other environmental catastrophes have plagued African resource managers throughout history. The sustained development of forest resources is central to coping with these issues because the rural, agrarian human population relies significantly on forest ecosystems for food, fuel, fiber, employment, and income (Gregerson et al. 1989). Land use and global climate change threats to African forest resources are significant in the near-and long-term (Winjum et al. 1993). Adaptation to global change may be a more feasible strategic goal for Cameroon and Ghana than intensive mitigation measures such as those proposed by developed nations (Rubin et al. 1992, Dixon et al. 1993).

The success of that adaptation will be influenced by landscape dynamics and by socio-cultural variables such as history. The landscape of West Africa is a mosaic of forest systems which has been sustainably managed by indigenous resource managers for centuries (Glantz \& Katz 1985). Resource-poor farmers often adapt to a changing environment or to other constraints in order to sustain production of food, fiber, fuel, and other goods for survival (MacDicken \& Vergara 1990). While anticipatory adaptation in response to global climate change may be the most risk averse strategy for governments (Schneider 1989), few developing countries have the human or institutional resources to implement such a strategy (Gleick 1985). A reactionary, adaptive response to climate change may be more financially and logistically realistic, given the agrarian and developing economies of countries such as Cameroon and Ghana. The history and experience of adaptation in developing countries may enable them to avoid severe impacts encountered by developed countries (Smith \& Tirpak 1989) in a rapidly changing global climate (Schneider 1989).

However, that history and its implications vary among countries. For example, French colonies were subject to an assimilationist experience in which management at the local, regional and national level was inherently French. Due to that history, little indigenous infrastructure remains at the local level. In contrast, British colonies underwent a more remote colonial experience which relied on local, indigenous infrastructures to implement British policies and goals, but often favored specific ethnic groups. Adaptive responses to global change in West African forests will require local scale flexibility in response to uncertain 
futures (Adelman et al. 1992). Indigenous cultures and management strategies will be more successful in those responses than will infrastructures and value systems imported from abroad.

Acknowledgements. This research was partially supported by a grant from the International Division of the U.S. National Science Foundation to R.K.D. and J.A.P.

\section{LITERATURE CITED}

Adelman I, Morris CT, Fetini H, Golan-Hardy E (1992) Institutional change, economic development and the environment. Ambio 21:106-110

Alpert P (1993) Conserving biodiversity in Cameroon. Ambio $22: 44-49$

Barnes RFW (1990) Deforestation trends in tropical Africa. African Journal of Ecology 28: 161-173

Barrett-Lennard EG, Malcolm CV, Stern WR, Wilkins SM (eds) (1986) Forage and fuel production from salt-affected wasteland. Elsevier Science Publishing, New York, NY

Boonkird SA, Fernandes ECM, Nair PKR (1991) Forest villages: an agroforestry approach to rehabilitating forest land degraded by shifting cultivation in Thailand. In: Nair PKR (ed) Agroforestry systems in the tropics. Kluwer Academic Publishers, Boston, MA, p 211-228

Brown S, Hall CAS, Knabe W, Raich J, Trexler MC, Woomer P (1993) Tropical forests: their past, present and potential future role in the terrestrial carbon budget. Water Air Soil Pollut 70:71-94

Bushbacher RJ (1992) Natural forest management in the humid tropics: ecological, social and economic considerations. Ambio 19:253-258

Dixon RK, Andrasko KJ, Sussman FA, Lavinson MA, Trexler MC, Vinson TS (1993) Forest sector carbon offset programs: near-term opportunities to reduce greenhouse gas emissions to the atmosphere. Water Air Soil Pollut 70 : $561-577$

Dixon RK, Brown S, Houghton RA, Solomon AM, Trexler MC, Wisniewski J (1994) Carbon pools and flux of global forest systems. Science 263:185-190

Dixon RK, Perry JA, Hiol Hiol F (1996) Carbon sequestration and conservation in forest systems: preliminary assessments in Cameroon and Ghana. Water Air Soil Pollut (in press)

Foley G (1987) Exaggerating the Sahelian fuelwood problem? Ambio 16:367-371

Gartlan JS, Newberry DM, Thomas DW, Waterman PG (1986) The influence of topography and soil phosphorus on the vegetation of Korup Forest Reserve, Cameroon. Vegetatio 65:131-148

Gilbert FG, Perry JA, Booth G (1995) Preliminary assessment of environmental issues and a strategic approach for US AID Ghana. World Resources Institute, Washington, DC

Glantz MH, Katz RW (1985) Drought as a constraint to development in sub-Saharan Africa. Ambio 14:334-339

Gleick PH (1989) Climate change and international politics: problems facing developing countries. Ambio 18:333-338

Graham RL, Perlack RD, Prasad AMG, Ranney JW, Waddle DB (1990) Greenhouse gas emissions in sub-Saharan Africa. U.S. Department of Energy, Oak Ridge National Laboratory, No. ORNL-6640

Grainger A (1988) Estimating areas of degraded tropical lands requiring replenishment of forest cover. Int Tree Crops J 5:31-61
Gregerson H, Draper S, Elz D (1989) People and trees: the role of social forestry in sustainable development. EDI Seminar Series, The World Bank, Washington, DC

Hall DO, Rosilo-Calle F (1990) African forests and grasslands: sources or sinks of greenhouse gases. In: Proceedings of international conference on global warming and climate change: African perspectives. United Nations Environment Program (UNEP), Nairobi, p 1-23

Hall JB, Swaine MD (1981) Distribution and ecology of vascular plants in a tropical rain forest: forest vegetation in Ghana. Dr W Junk Publishers, The Hague

Hansen J, Russel G, Rind D, Stone P, Lacis A, Lebedeff $S$, Ruedy $R$, Travis L (1983) Efficient three-dimensional global models for climate studies: models I and II. Mon Weather Rev 11:609-662

Hellden $U$ (1992) Desertification-time for an assessment. Ambio 20:372-383

Hogan KP, Leng RA (1992) Methane emissions from ruminants in semi-arid regions. In: Boag $\mathrm{S}$ (ed) Proceedings of workshop: assessing technologies and management systems of agriculture and forestry in relation to climate change. Australian Government Publishing Service, Canberra, p 102-104

Holdridge LR (1967) Life zone ecology. Tropical Science Center, San Jose, CA

IPCC (1995) Working Group I Report. Intergovernmental Panel on Climate Change, Geneva, in press

Iverson LR, Brown S, Grainger A, Prasad A, Liu D (1993) Carbon sequestration in tropical Asia: an assessment of technically suitable forest lands using geographic information analysis. Clim Res 3:23-28

Krankina ON, Dixon RK (1993) Forest management options to conserve and sequester terrestrial carbon in Russia. World Resour Rev 6:88-101

Lugo AE, Parrotta JA, Brown S (1993) Loss in species caused by tropical deforestation and their recovery through management. Ambio 22:106--109

Lugo AE, Sanchez MJ, Brown S (1986) Land use and organic carbon content of some subtropical soils. Plant Soil 96 : $185-196$

MacDicken KG, Vergara NT (1990) Agroforestry: classification and management. Wiley, New York

Manabe S, Wetherald RT (1987) Large-scale changes in soil wetness induced by an increase in carbon dioxide. $J$ Atmos Sci 44:1211-1235

McArthur RH, Wilson EO (1967) The theory of island biogeography. Monographs in Population Biology. Princeton University Press, Princeton, NJ

Mitchell JFB (1989) The greenhouse effect and climate change. Rev Geophys 27:115-139

Neilson RP, King GA, Koerper G (1991) Towards a rule-based biome model. Landsc Ecol 7:27-43

Neilson RP, King GA, Lenihan J (1994) Modeling forest response to climatic change: the potential for large emissions of carbon from dying forests. In: Kaaninen $M$ (ed) Carbon balance of the world's ecosystems: toward a global assessment. Finland Academy of Science, Helsinki, p $150-162$

Prentice IC, Harrison SP, Leemans R, Monserud RA, Solomon AM (1992) A global biome model based on plant physiology and dominance, soil properties and climate. J Biogeogr 19:117-134

Rubin ES, Cooper RM, Frosch RA, Lee TH, Marland G, Rosenfeld AH, Stine DD (1992) Realistic mitigation options for global warming. Science 257:148-266

Sampson RN, Wright LL, Winjum JK, Kinsman JD, Benneman J, Kürsten E, Scurlock JMO (1993) Biomass management 
and energy. Water Air Soil Pollut 70:139-159

Sanchez PA, Benites JR (1987) Low-input cropping for acid soils of the humid tropics. Science 238:1521-1527

Schlessinger ME, Zhao ZC (1989) Seasonal climatic change introduced by doubled $\mathrm{CO}_{2}$ as simulated by the OSU atmospheric GCM/mixed-layer ocean model. J Clim 2: $429-495$

Schneider SJ (1989) The greenhouse effect: science and policy. Sclence 243:771-781

Singh KD (1993) Forest resources assessment 1990: tropical countries. FAO Forestry Paper 112. Food and Agriculture Organization of United Nations, Rome

Smith JB, Tirpak DA (1989) The potential effects of climate change on the United States. EPA-230-05-89-050, U.S. Environmental Protection Agency, Washington, DC
Smith TM, Cramer WP, Dixon RK, Leemans R, Neilson RP, Solomon AM (1993) The global terrestrial carbon cycle. Water Air Soil Pollut 70:19-38

Smith TM, Shugart HH, Bonan GB, Smith JB (1991) Modelıng the potential response of vegetation to global climate change. Adv Ecol Res 22:93-116

Trexler MC, Haugen CM (1995) Keeping it green: evaluating tropical forestry strategies to slow global warming. World Resources Institute, Washington, DC

Unruh JD, Houghton RA, LeFebvre PA (1993) Carbon storage in agroforestry: an estimate for sub-Saharan Africa. Clim Res 3:39-52

Winjum JK, Meganck RA, Dixon RK (1993) Expanding global forest management: an easy-first proposal. J For $91: 38-42$ 